\title{
ASSEMBLY LINE DESIGN THROUGH SOFTWARE TECNOMATIX MODULE PROCESS DESIGNER
}

\author{
Jozef Trojan \\ Technical University of Kosice, Faculty of Mechanical Engineering, Institute of Management, Industrial and Digital \\ Engineering, Park Komenskeho 9, 04200 Kosice, Slovakia, EU, jozef.trojan@ @uke.sk (corresponding author) \\ Peter Trebuňa \\ Technical University of Kosice, Faculty of Mechanical Engineering, Institute of Management, Industrial and Digital \\ Engineering, Park Komenskeho 9, 04200 Kosice, Slovakia, EU, peter.trebuna@ tuke.sk

\section{Marek Mizerák} \\ Technical University of Kosice, Faculty of Mechanical Engineering, Institute of Management, Industrial and Digital \\ Engineering, Park Komenskeho 9, 04200 Kosice, Slovakia, EU, marek.mizerak@tuke.sk

\section{Richard Duda} \\ Technical University of Kosice, Faculty of Mechanical Engineering, Institute of Management, Industrial and Digital \\ Engineering, Park Komenskeho 9, 04200 Kosice, Slovakia, EU, richard.duda@tuke.sk
}

Keywords: Assembly process, Process Designer, Process Simulate

Abstract: The present article is devoted to designing the analysed workstation model using Process Designer, where individual outputs can help identify potential shortcomings. Process Designer is a widely used module. It is possible to statically design a workplace layout and analyse future production by creating a simulation of individual manufacturing activities. Subsequently, it contains suggestions to eliminate these deficiencies, which were found using the software as mentioned above.

\section{Introduction}

Every company, and especially engineering companies, needs some change over their lifecycle. A few years ago, all firms modified their assembly processes, and material flows by testing and testing possible alternatives on the running system. Therefore, if the company wanted to change the assembly line layout, it had to create and schedule all activities on paper. Then these scheduled activities could be implemented in the real system. The problem was that no one could determine the success or failure of the project, and any inconsistency in the implementation of the change had to be dealt with immediately when the error occurred. This caused a time loss, a reduction in production capacity and, last but not least, a financial loss. It is not possible at this time. Almost all of the world's big businesses share the philosophy of a digital business. A digital enterprise is a kind of strategy where the company works with digital 3D models of real production, making changes and optimising them. It is possible to try several alternatives in a few moments before being introduced into a real running system [1].

\section{Description of an analysed assembly line}

The assembled assembly line completes the doubleclutch automatic transmission. The analysed workplace consists of two assembly lines representing one of the most important workplaces of the company. The final assembly of the gearbox takes place on these two assembly lines, i.e. the assembly of the individual parts from the gearbox itself, through the gears, shafts, to the closing of the gearbox and transfer to another workplace [2]. The following diagram (Figure 1) shows the basic layout of MPS I and MPS II assembly lines.

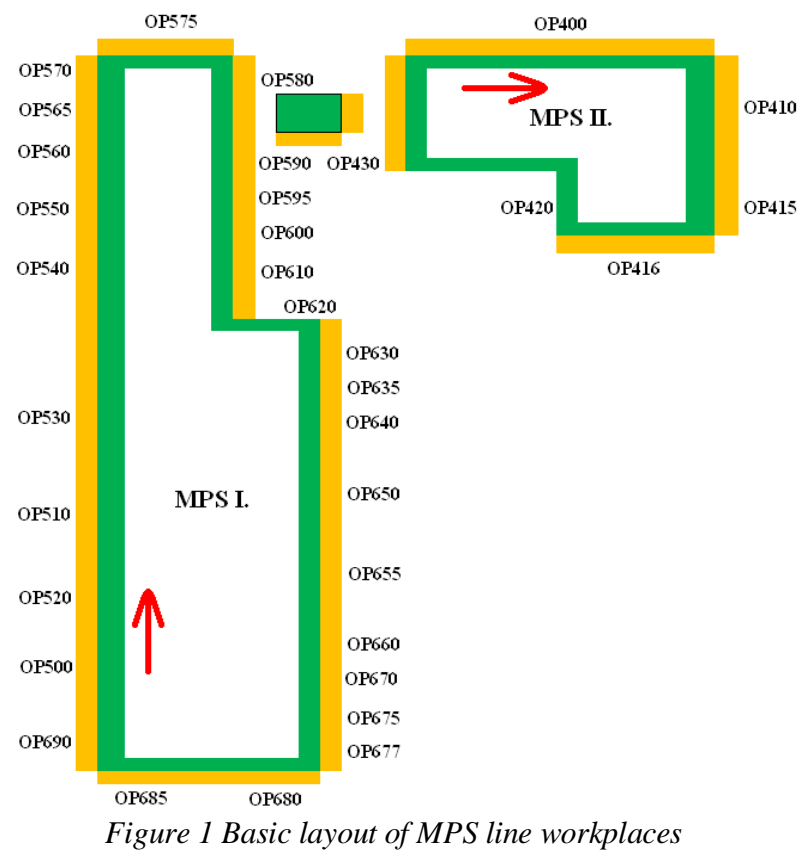
$\sim 7 \sim$ 
The assembly line MPS I has dimensions of approximately $40 \mathrm{~m} \times 6 \mathrm{~m}$ and the line MPS II. has $6 \mathrm{~m} \times$ $7 \mathrm{~m}$. MPS II assembly line is an auxiliary line for MPS I. as it is fitted with a set of input and output shafts together with gear wheels? This set is then moved to the MPS I line where the gearbox assembly continues. Individual operations are referred to as OPs together with a three-digit number.

\section{Create a project}

The Project Designer project is based on three units that need to be defined. First of all, we need to define the product - what will be produced or optimised. All parts of the product must be defined. Furthermore, it is necessary to define the resources needed to produce the product and the third point is the process - the definition of how to produce the product through resources.

Process Designer has a special data usage concept. Only one type is possible. All imported data must be in JT format. This can be done by converting files (3D product models or resources) using Autodesk software (such as Inventor or Factory Design), Solid Edge or NX. It is also necessary to save individual files to the directory with the extension .cojt to use these models in Process Designer [3].

When you run Process Designer (log in and select Open project window), you have to choose between two options. You can open an existing project from the Open project window or from the File - Import New eBOP main menu and then find the. $\mathrm{xml}$ file in the directory on the disk. If we want to create a new project, the option File (from the main menu) and New project is again. After entering the project name and confirming the selection by clicking OK, the new project is created.

Subsequently, it is necessary to create product libraries in Tools - Administrative tools - Create Engineering Libraries menu and select the folder where the product part files are located and finally assign the PartPrototype to all JT files.

After creating a product library, you need to create a CompoundPart folder to display it in the graphics window by right-clicking on the project name and selecting New and then selecting CompoundPart. To complete this operation, just move parts from the library to the newly created CompoundPart folder [4].

In a similar way, you need to create a resource library to store and retrieve resources (machines, devices, workforce, robots, etc.). Right-click on the project name and select New to select ResourceLibrary. It is possible to populate the library by right-clicking on the library name New and then selecting the desired object types (Figure 2).

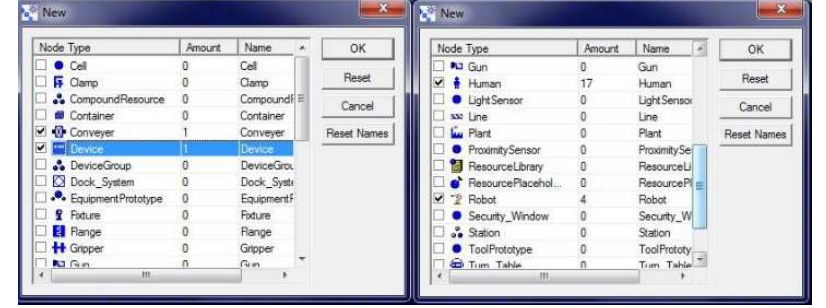

Figure 2 Create a library of resources and their objects

Furthermore, it is possible to import .jt files of individual sources into the created library structure. Rightclick on the created object (e.g. Robot) to select Properties, the Physical tab and then specify the path to the .jt file for the $3 \mathrm{D}$ file window.

The basic Process Designer structure is based on the relationship between product, resources, and processes. Product components and resources have been defined in libraries and will later be assigned to processes [5].

\section{Project outputs}

One of the outcomes of the project is the 3D layout of the workplace, which can be seen in Figure 3. Such a design is certainly important in planning and optimising production processes, but Process Designer has a number of interesting outputs for further analysis. One of the possibilities of this software is the definition of processes and their distribution for time analysis. Time analysis can be displayed using the generated Gantt Chart. By rightclicking on the selected process (s) or on the first item in the tree structure and selecting Gantt Viewer, the desired graph is displayed in a new window [6].

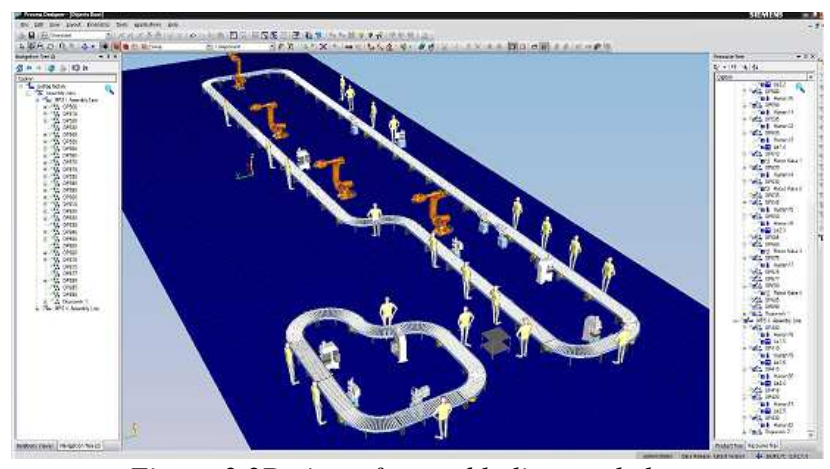

Figure 3 3D view of assembly line workplaces

The Gantt chart can be largely modified. More precisely, relationships between activities can be defined. Left-click on the desired first and subsequent operations with the CTRL key to mark these actions in the graph. Then just create a connection between them by clicking on the Link Operations icon [7].

Of course there is a possibility to adjust the times of individual activities via Properties and Allocated Time as well as when defining process creation times. 


\section{ASSEMBLY LINE DESIGN THROUGH SOFTWARE TECNOMATIX MODULE PROCESS DESIGNER}

Jozef Trojan; Peter Trebuňa; Marek Mizerák; Richard Duda

As described above, the Gantt chart becomes a real production image on the MPS assembly line. The activities are shown in the diagram using rectangles whose size represents the duration of each activity. The relationships established between these activities show the black arrows between the rectangles. At the same time, the direction of the arrow indicates the continuity of the two activities, respectively their sequence. The resulting Gantt plot of the assembly line can be seen in the following diagram (Figure 4). It is a simple diagram where individual operations and activities follow each other [8].

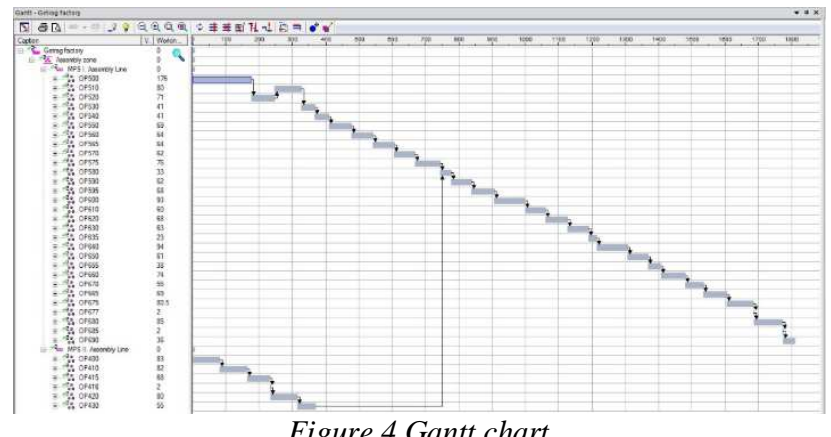

Process Designer, respectively. Gantt chart analysis has several quick features such as Display Longest Path. It is the duration of the whole process (the whole production), in the case of the structure created above it is the total time of operations on the line [9].

At the same time, Process Designer allows you to display the length of this path in the time units that were used to define the times for each activity. To view this time, you need to hold the mouse cursor on the blue line corresponding to the longest path. For this project, this value also represents the total assembly time of one gearbox, which is 1810.5 seconds at the start time of 0 seconds.

Process Designer can also assign resources, material flow, and process costs. By selecting the Properties option of the operation, you can edit a number of production attributes in each tab of that function [10].

Another useful output from Process Designer is the flowchart. With the left mouse click and the CTRL key, all OP operations needed for the flowchart can be marked. Right-click and select Pert Viewer to display the desired diagram. However, it is not suitable for output. Most cells are stacked on top of each other, and the links created from the previous Gantt chart are opaque. By left-clicking on the cells and moving them, the diagram is displayed in a schematic diagram (Figure 5).

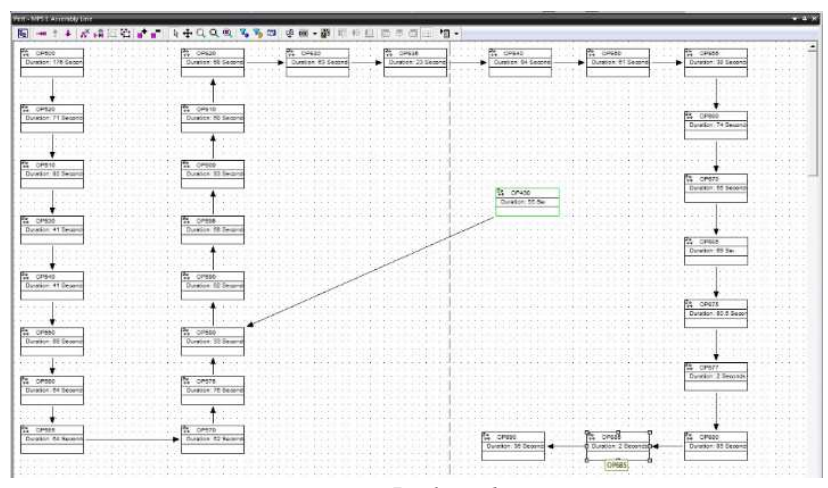

Figure 5 Flowchart

The resulting flowchart in Process Designer is able to display a sequence of processes where it is again possible to modify relationships between tasks or processes, duration, and if necessary, rearrange the production system to improve the original. The individual cells in the diagram contain the time assigned to the activity in addition to the OP operation name. The arrows between the cells refer to the continuity of the operations [11].

\section{Proposal of optimisation of analysed assembly line}

Based on the analysis of the selected MPS assembly line and the individual outputs using Tecnomatix Process Designer software, there were little shortcomings in the use of resources during assembly. Specifically, it is an assembly line MPS I. and workplaces OP540 and OP610 (Figure 6).

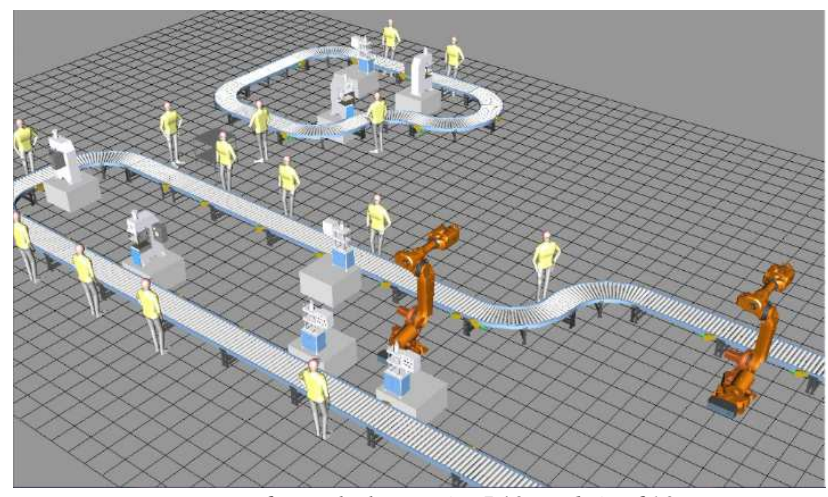

Figure 6 Workplaces OP540 and OP610

\subsection{Original state of OP540 and OP610 optimised workplaces}

In addition to stamping, the OP540 also performs the lubrication of the gearbox component. This activity is performed by one worker on the line. After the lubrication is completed, the operator moves along with the gearbox to OP550, where he presses the bearings. Compared to the OP540 workstation, robot sealing is applied to OP610. The total operation time of OP540 is 41 seconds, where the transmission waiting time is 2 seconds, the component is 


\section{ASSEMBLY LINE DESIGN THROUGH SOFTWARE TECNOMATIX MODULE PROCESS DESIGNER}

Jozef Trojan; Peter Trebuňa; Marek Mizerák; Richard Duda

pressed for 24 seconds, and the above-mentioned lubrication is 15 seconds. The following diagram (Figure 7) shows a detailed view of the optimised workstations in the original layout.

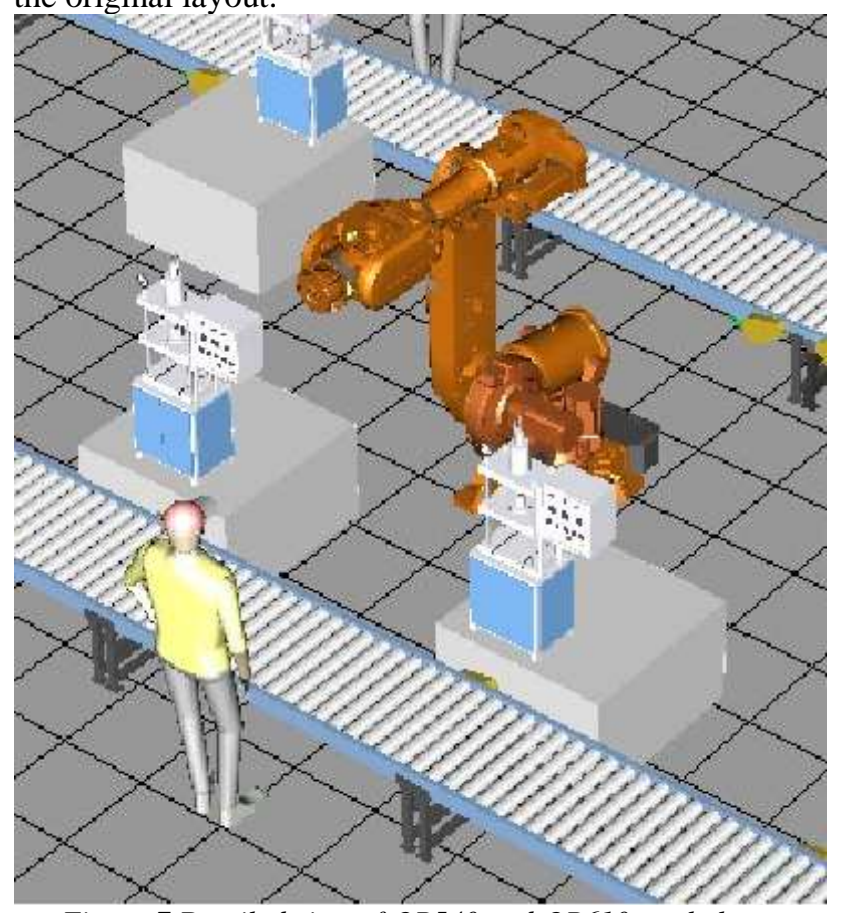

Figure 7 Detailed view of OP540 and OP610 workplaces

\subsection{Proposed optimisation of OP540 and OP610 workplaces}

The operation of lubrication of the gearbox component can be replaced by suitable synchronisation with the workplace OP610. This operation of applying the seal to the gearbox is carried out by the KUKA robot with a time of 60 seconds. The previous operation is OP600, which lasts 93 seconds. As a result, OP610 is a bottleneck. This downtime can be utilised by component lubrication activity. The OP610 Robot has a 33 second time reserve. The total robot time required to lubricate the transmission component is 7 seconds, saving 8 seconds from the previous worker lubrication time (15 seconds). The assembly line has a production cycle of 120 seconds. This means that every single piece of assembled gearbox leaves the conveyor belt every 120 seconds. The total saving of 8 seconds increases the production cycle to 112 seconds. The assembly line works in a 3 - shift operation where one change takes 8 hours. Thus, 720 pieces of gearboxes per working day were produced prior to optimisation. After optimising the installation time, the line is capable of producing 771 units, an increase of 51 gearboxes. The percentage increase in production is about $7 \%$, which is not a negligible number. Thus, human activity will be replaced by a faster, more accurate robot, and its efficient utilisation will be greater than in the original arrangement. However, this proposal is necessary to eliminate possible collisions and new downtime of other workplaces. This stems from the tact of production and thus the continuous continuity of individual operations may be disrupted by the proposed changes. Using the Display Longest Path function, a change in the total time required to produce one gearbox was found. It was shortened from the original 1810.5 to the resulting 1802.5 seconds.

The advantage of this optimisation is to it minimise the cost of change. There is no change in the workplace layout as OP540 is in close proximity to the Robot on OP610. However, it is necessary to reprogram the Robot that will perform the extra activity while ensuring Robot's safety by exposing the appropriate barriers and safety sensors [12]. Since the company could not provide the individual prices of these items and some of the works can be procured on its own, it was not possible to quantify the total price for the proposed optimisation (Figure 8).

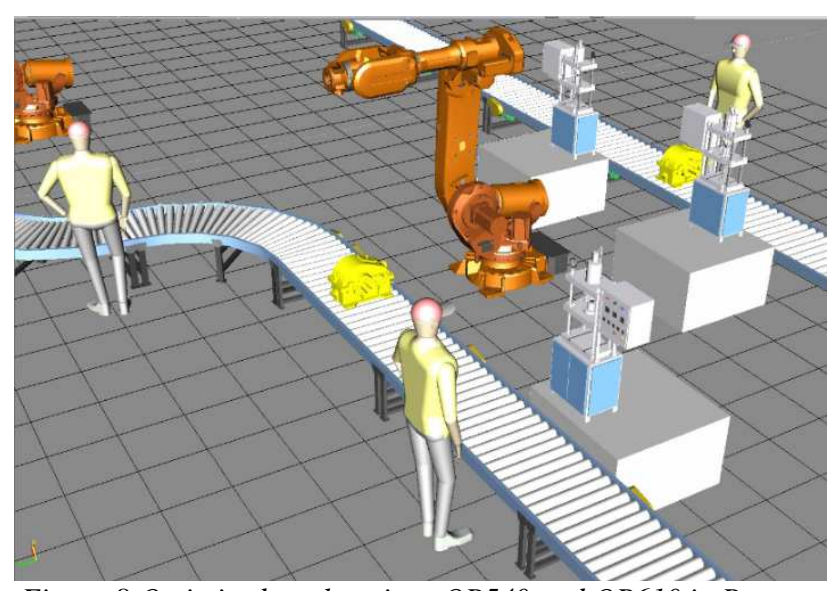

Figure 8 Optimised workstations OP540 and OP610 in Process Designer module

\section{Conclusion}

In the present work, I dealt with analysing and modelling the selected assembly line in the company. I used the Siemens Tecnomatix Process Designer software to analyse assembly processes. I looked for possible shortcomings in the operations of individual operations for static 3D models of production and individual outputs such as Gantt or Flowchart. After optimisation of the OP540 and OP610 workplaces, an increase in production volume of $7 \%$ was found by calculation.

Planning, optimising and managing production and assembly processes can take a lot of time. This basic overview of Siemens, all design and production operations, can be done in the Tecnomatix platform. Its Process Designer module shows that in a short time, with feedback and without financial losses. It is possible to select the necessary tools to ensure the balance of the assembly line by optimising the processes or activities of the workers who create the resources for the production processes. In the end, the manager will have a comprehensive overview of the entire project, a precise system layout, timeconsuming and material flow, whereby the company can 
increase its productivity, make better use of resources and be ready to make quick decisions or changes [13-17]. It can be said that software such as Siemens Tecnomatix Process Designer will automatically analyse the production processes of all companies in the future, but also the fact that such solutions are necessary and very useful for all larger companies today.

\section{Acknowledgement}

This article was created by implementation of the grant project APVV-17-0258 "Digital engineering elements application in innovation and optimisation of production flows", APVV-19-0418 "Intelligent solutions to enhance business innovation capability in the process of transforming them into smart businesses", VEGA $1 / 0438 / 20$ "Interaction of digital technologies to support software and hardware communication of the advanced production system platform" and KEGA 001TUKE4/2020 "Modernising Industrial Engineering education to Develop Existing Training Program Skills in a Specialized Laboratory" and University Science Park TECHNICOM for Inovation Application Supported by Knowledge Technology, ITMS: 26220220182, supported by the Research and Development Operational Program funded by the ERDF.

\section{References}

[1] BANGSOW, S.: Tecnomatix Plant Simulation, Springer International Publishing AG Switzerland, 2016.

[2] BARBUŠOVÁ, M., MEDVECKÁ, I., DULINA, L'.: Systém merania produktivity $\mathrm{V}$ podniku, Fórum manažéra: teória a prax v riadení podniku, Vol. 2018, No. 2, pp. 3-11, 2018. (Original in Slovak)

[3] DULINA, L., RAKYTA, M., SULÍROVÁ, I., ŠELIGOVÁ, M.: Improvement of the production system, Smart City $360^{\circ}, 2^{\text {nd }} E A I$ international summit: revised selected papers, Vol. 1, pp. 1-13, 2017.

[4] MIČIETA B., EDL M., KRAJČOVIČ M., DULINA L', BUBENÍK P., ĎURICA L., BIŇASOVÁ V.: Delegate MASs for coordination and control of one-directional AGV systems: a proof-of-concept, The International journal of Advanced Manufacturing technology, Vol. 94, pp. 415-431, 2018.

[5] GRAINER: How to Increase Energy Efficiency with Machine Tools, [Online], availabe: https://www.grainger.com/content/supplylink-how-toincrease-energy-efficiency-with-machine-tools [10 Jan 2020] 2019.

[6] HEINICKE, M.: Optimized Energy Efficiency with Tecnomatix, SIEMENS, [Online], available: www.siemens.com/plm [10 Jan 2020] 2019

[7] KRUSE, A., UHLEMANN, T., STEINHILPER, R.: Simulation-based assessment and optimisation of the energy consumption in multi variant production, ScienceDirect, Elsevier, $13^{\text {th }}$ Global Conference on Sustainable Manufacturing, 2016. doi:10.1016/j.procir.2016.01.075

[8] WOROBEL, R., ČAPEK, J., KOVÁČOVÁ, L., BUBENÍK, P., KRAJČOVIČ, M.: Improving business processes using simulation tools, MM Science Journal, Vol. 2018, No. March, pp. 2244-2251, 2018.

[9] Siemens PLM Solutions: Plant, line and process simulation and optimisation, [Online], available: http://www.simsol.co.uk/ [10 Jan 2020] 2008.

[10] VAVRÍK V., GREGOR M., GRZNÁR P.: Computer simulation as a tool for the optimisation of logistics using automated guided vehicles, Procedia Engineering, Vol 192, pp. 923-928, 2017.

[11] KOVÁČ, J., SVETLÍK, J., DRABIKOVÁ, E.: Use of mixed reality in dismanting of components, Sovremennyje koncepciji razvitija nauky, Ufa: Omega Science, 2018.

[12] KLIMENT, M., POPOVIČ, R., JANEK, J.: Analysis of the Production Process in the Selected Company and Proposal a Possible Model Optimisation Through PLM Software Module Tecnomatix Plant Simulation, Procedia Engineering: Modelling of Mechanical and Mechatronic Systems MMaMS 2014: 25th-27th November 2014, High Tatras, Slovakia, Vol. 96 2014, pp. 221-226, 2014.

[13] PEKARCIKOVA, M., TREBUNA, P., MARKOVIC, J.: Case study of modelling the logistics chain in production, Modelling of Mechanical and Mechatronic Systems (MMaMS), Book Series: Procedia Engineering, Vol. 96, pp. 355361, 2014.

[14] RUDY, V., MALEGA, P., KOVÁČ, J.: New Approaches to Designing Production System Structures, Acta Mechanica Slovaca, Vol. 23, No. 1, pp. 14-21, 2019.

[15] TREBUŇA, P,. KLIMENT, M., EDL, M., PETRIK, M.: Creation of Simulation Model of Expansion of Production in Manufacturing Companies, Procedia Engineering: Modelling of Mechanical and Mechatronic Systems MMaMS 2014: 25th-27th November 2014, High Tatras, Slovakia. Vol. 96, 2014, pp. 477-482, 2014.

[16] TREBUŇA, P., KOTTFER, D., PEKARČÍKOVÁ, M., PETRIKOVÁ, A., POPOVIČ, R., REHÁK, F., ČIŽNÁR, P.: Evaluating the replacement of galvanic Cr coatings, Polish Journal of Environmental Studies, Vol. 27, No. 3, pp. 1289-1296, 2018.

[17] KULA, T., BOCKO, J., KOSTKA, J., FRANKOVSKÝ, P.: Analysis of axially compressed cylindrical shells influenced by geometrical imperfections using finite element method, In: Experimental Stress Analysis 2017, EAN 2017, Novy Smokovec, Slovakia, pp. 193-200, 2017. 